\title{
Peat Water Treatment Using Combination of Cationic Surfactant Modified Zeolite, Granular Activated Carbon, and Limestone
}

\author{
S. Syafalni ${ }^{1}$, Ismail Abustan ${ }^{1}$, Aderiza Brahmana ${ }^{1}$, Siti Nor Farhana Zakaria $^{1} \&$ Rohana Abdullah ${ }^{1}$ \\ ${ }^{1}$ School of Civil Engineering, Engineering Campus, Universiti Sains Malaysia, Nibong Tebal, Penang, Malaysia. \\ Correspondence: S. Syafalni, School of Civil Engineering, Engineering Campus, Universiti Sains Malaysia, \\ Nibong Tebal 14300, Penang, Malaysia. E-mail: cesyafalni@eng.usm.my
}

Received: December 3, 2012

doi:10.5539/mas.v7n2p39
Accepted: January 14, 2013 Online Published: January 22, 2013

URL: http://dx.doi.org/10.5539/mas.v7n2p39

\begin{abstract}
This research was conducted essentially to treat fresh peat water using a series of adsorbents. Initially, the characterization of peat water was determined and five parameters, including $\mathrm{pH}$, colour, $\mathrm{COD}$, turbidity, and iron ion exhibited values that exceeded the water standard limit. There were two factors influencing the adsorption capacity such as $\mathrm{pH}$, and adsorbent dosages that were observed in the batch study. The results obtained indicated that the majority of the adsorbents were very efficient in removing colour, COD, turbidity at $\mathrm{pH}$ range $2-4$ and $\mathrm{Fe}$ at $\mathrm{pH}$ range 6-8. The optimum dosage of cationic surfactant modified zeolite (CSMZ) was found around $2 \mathrm{~g}$ while granular activated carbon (GAC) was exhibited at $2.5 \mathrm{~g}$. In column study, serial sequence of CSMZ, GAC, and limestone showed that the optimal reduction on the 48 hours treatment were found $\mathrm{pH}=7.78$, colour $=12 \mathrm{TCU}$, turbidity $=0.23 \mathrm{NTU}, \mathrm{COD}=0 \mathrm{mg} / \mathrm{L}$, and $\mathrm{Fe}=0.11 \mathrm{mg} / \mathrm{L}$. Freundlich isotherm model was obtained for the best description on the adsorption mechanisms of all adsorbents.
\end{abstract}

Keywords: cationic surfactant modified zeolite, granular activated carbon, limestone, peat water

\section{Introduction}

Water is essential and fundamental to all living forms and is spread over $70.9 \%$ of the earth's surface. However, only $3 \%$ of the earth's water is found as freshwater, of which $97 \%$ is in ice caps, glaciers and ground water (Bhatmagar \& Minocha, 2006). In Malaysia, more than $90 \%$ of fresh water supply comes from rivers and streams. The demand for residential and industrial water supply has grown rapidly coupled with an increase in population and urban growth (WWF Malaysia, 2004). Water demand in affected populations such as rural areas also demands that attention is paid to providing more sustainable solutions rather than transporting bottled water (Loo et al., 2012). For this reason, it is essential to ensure availability of local sources of water supply and even develop new potential sources of water such as from peat swamp forest to overcome future water shortages.

River water surrounded by peat swamp forest is defined as peat water and is commonly available as freshwater since it has a low concentration of salinity. The previous study shows that peat swamp forest has high levels of acidity and organic material depending on its region and vegetation types (Huling et al., 2001). Under natural conditions, tropical peat lands serve as reservoirs of fresh water, moderate water levels, reduce storm-flow and maintain river flows, even in the dry season, and they buffer against saltwater intrusion (Wosten et al., 2008).

Due to the acidity and high concentration of organic material, selective treatment of peat water must be conducted prior to its use as water supply. Recently, many methods have been designed and have proven their effectiveness in treating raw water such as coagulation and flocculation (Franceschi et al., 2002; Liu et al., 2011; Syafalni et al., 2012a), absorption (Ćurković et al., 1997), filtration (Paune et al., 1998) and combining (Hidaka et al., 2003). Careful consideration of the most suitable method is important to ensure that the adsorption process is the most beneficial, economically feasible method as well as easy to operate for producing high quality of water in a particular location.

Many researchers have shown that activated carbon is an effective adsorbent for treating water with high concentrations of organic compounds (Eltekova et al., 2000; Syafalni et al., 2012b). Its usefulness derives mainly from its large micropore and mesopore volumes and the resulting high surface area (Fu \& Wang, 2011). However, its high initial cost makes it less economically viable as an adsorbent. Low cost adsorbent such as zeolite nowadays has been explored for its ability in many fields especially in water treatment. Natural zeolite has negative surface 
charge which gives advantages in absorbing unwanted positive ions in water such heavy metal. These ions and water molecules can move within the large cavities allowing ionic exchange and reversible rehydration (Jamil et al., 2010). The effectiveness of zeolite has been improvised by modified zeolite with surfactant in order to achieve higher performance in removing organic matter ( $\mathrm{Li} \&$ Bowman, 2001). Among tested cationic surfactants, hexa-decyl-tri-methyl ammonium (HDTMA) ions adsorbed onto adsorbent surfaces are particularly useful for altering the surface charge from negative to positive (Chao \& Chen, 2012). Surfactant modified zeolite has been shown to be an effective adsorbent for multiple types of contaminants (Zhaohu et al., 1999).

Zeolite is modified to improve its capability of exchanging the anion by cationic surfactants, called CSMZ. CSMZ adsorbs all major classes of water contaminants (anions, cations, organics and pathogens), thus making it reliable for a variety of water treatment applications (Bowman, 2003). Nowadays, interest in the adsorption of anions and neutral molecules by surfactant modified zeolite has increased (Zhang et al., 2002). Modification of zeolite by surfactant is commonly done by cationic or amphoteric surfactants. By introducing surfactant to the zeolite, an organic layer is developed on the external surfaces and the charge is reversed to positive (Li et al., 1998). However, the present study used zeolite that had been modified using Uniquat (QAC-50) as cationic surfactant (CSMZ) and their performance towards the removal of color, COD, turbidity and iron ion from peat water were investigated.

\section{Materials}

Four adsorbents were used in these experiments which are natural zeolite, zeolite modified by cationic surfactant, activated carbon and limestone. All adsorbents were prepared with equivalent sizes of $1.18 \mathrm{~mm}-2.00 \mathrm{~mm}$. Hydrochloric acid $(\mathrm{HCl})$ and sodium hydroxide $(\mathrm{NaOH})$ were used for polishing zeolite during the preparation phase and for $\mathrm{pH}$ adjustment of the sample. Furthermore, potassium dichromate $\left(\mathrm{K}_{2} \mathrm{CrO}_{7}\right)$, silver sulphate $\left(\mathrm{Ag}_{2} \mathrm{SO}_{4}\right)$, sulphuric acid $\left(\mathrm{H}_{2} \mathrm{SO}_{4}\right)$ and mercury (II) sulphate $\left(\mathrm{HgSO}_{4}\right)$ were used as digestion solution reagents and acid reagents for COD analysis. Lastly, Uniquat (QAC-50) was used as cationic surfactant to modify the zeolite.

\subsection{Preparation of Surfactant Modified Zeolite}

In these studies, $100 \mathrm{~g}$ of prewashed natural zeolite was contacted with $5.6 \mathrm{ml} / 1$ Uniquat (QAC-50) as cationic surfactant (CSMZ). The mixture was then stirred at room temperature for 4 hours at $300 \mathrm{rpm}$ (Karadag et al., 2007). The zeolite then was filtered and washed with distilled water several times. After that, the absorbent was dried in an oven at a temperature of $105^{\circ} \mathrm{C}$ for 15 hours.

\subsection{Test Procedures}

\subsubsection{Batch Studies}

Serial batch studies were conducted at room temperature $\left(28 \pm 1{ }^{\circ} \mathrm{C}\right)$ to investigate the influence of $\mathrm{pH}$ and dosage for removing colour, COD, turbidity and iron ion from peat water. Shaking speed of $200 \mathrm{rpm}$ for 20 minutes were fixed and operated respectively. A working volume of $150 \mathrm{ml}$ peat water sample was set up in $250 \mathrm{ml}$ conical flasks. Preceding the batch studies, initial concentration for those parameters was determined. The optimum $\mathrm{pH}$ and dosage of absorbent were determined. Subsequently, the percentage of removal was finally determined, plotted, and compared.

\subsubsection{Batch Column Studies}

Column studies were carried out using a plastic column with dimensions: $5.4 \mathrm{~cm}$ diameter and $48 \mathrm{~cm}$ length. Three adsorbents were filled inside the column at a specific depth with the supporting layers of marbles, cotton wool, and perforated net. Total volume of $2000 \mathrm{ml}$ peat water was pumped in the up flow mode from the vessel into the column by using a Masterflex peristaltic pump at a minimum flow rate of $(30,60,90) \mathrm{ml} / \mathrm{min}$. In this study, however, column studies were performed un-continuously (batch) due to limitations of time. All parameters related to the column design are summarized in the following Table 1.

Table 1. Column studies parameters

\begin{tabular}{ccc}
\hline Parameters & Unit & Value \\
\hline Diameter, D & $\mathrm{cm}$ & 5.4 \\
Horizontal Surface Area, A & $\mathrm{cm}^{2}$ & 22.9 \\
Column volume, V & $\mathrm{cm}^{3}$ & 1099.3 \\
Flowrate, Q & $\mathrm{ml} / \mathrm{min}$ & $30,60,90$ \\
Surface Loading Rate, SLR=Q/A & $\mathrm{cm} / \mathrm{min}$ & $1.31,2.62,3.93$ \\
\hline
\end{tabular}


The serial sequence arrangements of adsorbents were conducted as shown in Figure 1 below. Effluent samples were collected at various time intervals, whilst maintaining room temperature, and analysed.

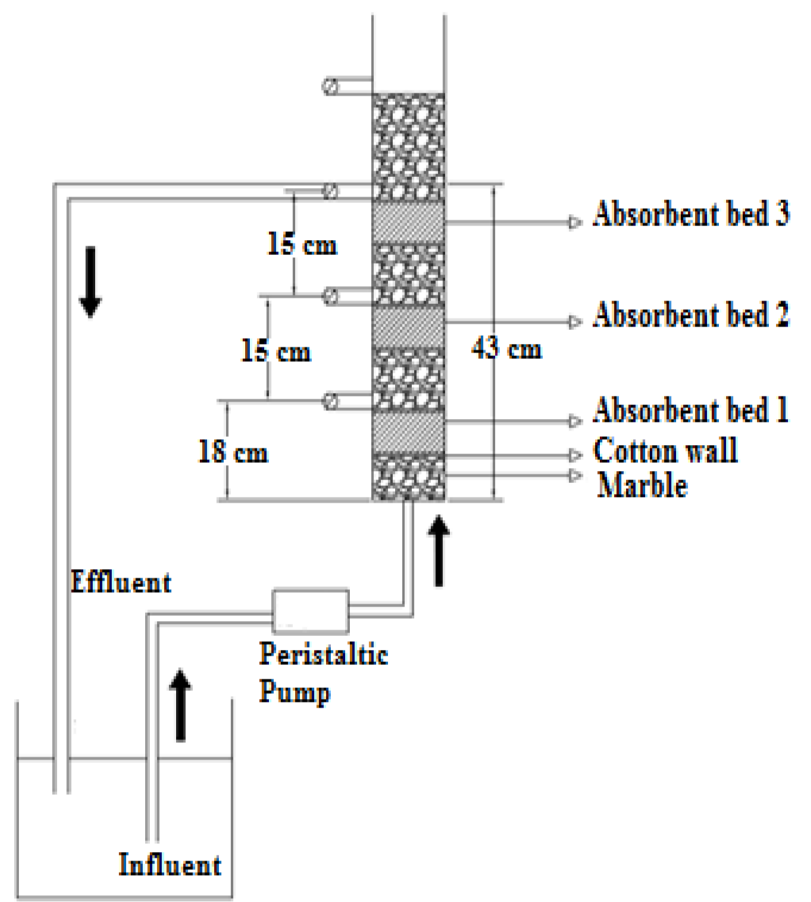

Figure 1. Schematic diagrams of lab-scale column studies

\section{Results and Discussion}

\subsection{Peat Water Characterization}

Surface water originating from the peat swamp forest was taken from Beriah peat swamp river along the Kerian River on several occasions as the main sample. The characterization of peat water was carried out at the sampling point (in-situ measurement) using a multi-parameter probe as well as in the environmental laboratory of civil engineering, USM. Fundamentally, the characterization procedures were based on the Standard Methods for the Examination of Water and Wastewater (APHA, 1992). Table 2 represents the peat water characteristics in average value and the comparison to the standard drinking water quality in Malaysia.

Table 2. The characteristics of peat water sample from Beriah Peat Swamp Forest

\begin{tabular}{ccc}
\hline Parameters & Unit & Average Value \\
\hline $\mathrm{pH}$ & - & $4.67-4.98$ \\
Temperature & ${ }^{\circ} \mathrm{C}$ & 27.8 \\
$\mathrm{TDS}$ & $\mathrm{mg} / \mathrm{L}$ & 20.6 \\
$\mathrm{DO}$ & $\mathrm{mg} / \mathrm{L}$ & 3.4 \\
Conductivity & $\mathrm{uS} / \mathrm{cm}$ & 34.5 \\
Salinity & $\mathrm{Ppt}$ & 0.02 \\
Color & $\mathrm{TCU}$ & 224.7 \\
Turbidity & $\mathrm{NTU}$ & 20.8 \\
COD & $\mathrm{mg} / \mathrm{L}$ & 33.3 \\
Iron, $(\mathrm{Fe})$ & $\mathrm{mg} / \mathrm{L}$ & 1.24 \\
$\mathrm{NH}_{3}-\mathrm{N}$ & $\mathrm{mg} / \mathrm{L}$ & 0.51 \\
\hline
\end{tabular}


Thirteen parameters were successfully determined where the first six parameters, including $\mathrm{pH}$, temperature, TDS, DO, conductivity, and salinity were measured at the sampling point, whilst the rest of the parameters, including colour, turbidity, $\mathrm{COD}$, iron ion, Ammoniacal Nitrogen, $\mathrm{NH}_{3}-\mathrm{N}$, Ammonia $\left(\mathrm{NH}_{3}\right)$, and Ammonium $\left(\mathrm{NH}^{+}\right)$were examined from the sample brought to the environmental laboratory on the same day.

Acidic $\mathrm{pH}$ of the peat water was predicted due to the composition of the surrounding peat soil itself which had been formed by decaying material possessing humic substances (Rieley, 1992). Besides that, humic substances also lead to the high organic content as humic substances are comprised of numerous oxygen containing functional group and fractions (humic acid, fulvic acids and humin) with different molecular weights which mean yielding high concentration of turbidity and COD as well as coloured water (Torresday et al., 1996). Moreover, composition of peat soil may also have an impact on the iron ion concentration of peat water (Botero et al., 2010).

From the thirteen parameters, five parameters were indicated exceeding the standard limit. These parameters were $\mathrm{pH}$, colour, turbidity, COD, and iron ion that showed values of $4.67-4.98,224.7 \mathrm{TCU}, 20.8 \mathrm{NTU}, 33.3 \mathrm{mg} / \mathrm{l}$, and $1.24 \mathrm{mg} / \mathrm{l}$ respectively while the standard limit of these parameters are $6.5-9.0,15 \mathrm{TCU}, 5 \mathrm{NTU}, 10 \mathrm{mg} / 1$, and 0.3 $\mathrm{mg} / \mathrm{l}$ accordingly.

\subsection{Effect of Initial pH on the Efficiency of Colour, COD, Turbidity, and Iron Ion ( $\mathrm{Fe}$ ) Removal}

Influence of initial $\mathrm{pH}$ on the adsorption capacity for removing colour, $\mathrm{COD}$, turbidity, and iron ion were investigated.

Figure 2(a) to Figure 2(d) below, displayed the percentage removal of colour, COD, turbidity, and iron ion against $\mathrm{pH}$ of adsorbents respectively.

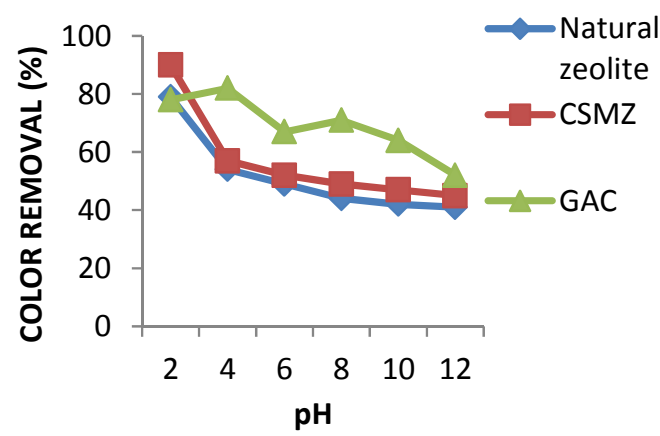

(a)

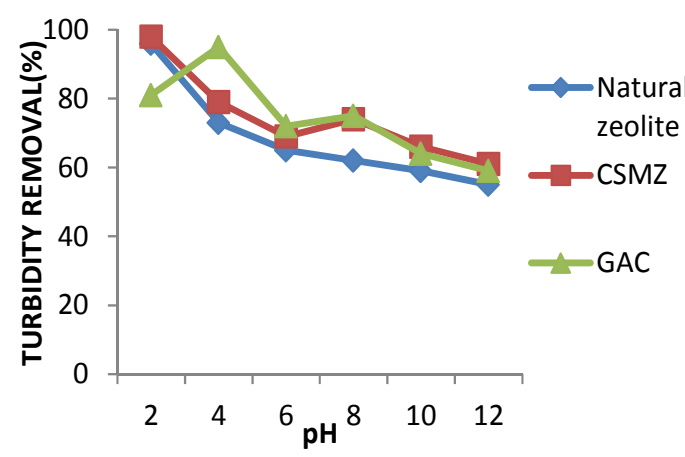

(c)

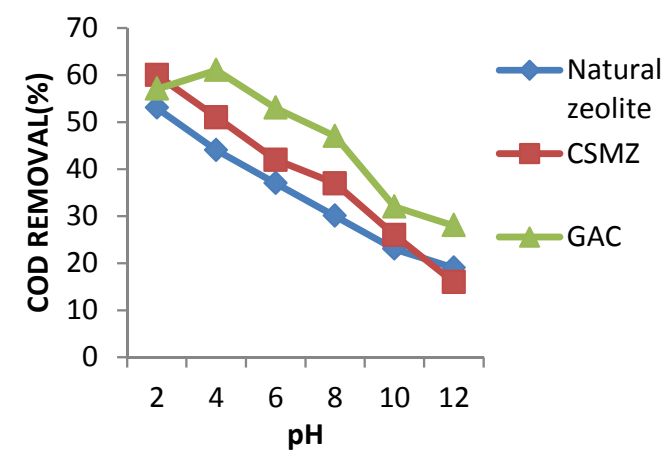

(b)

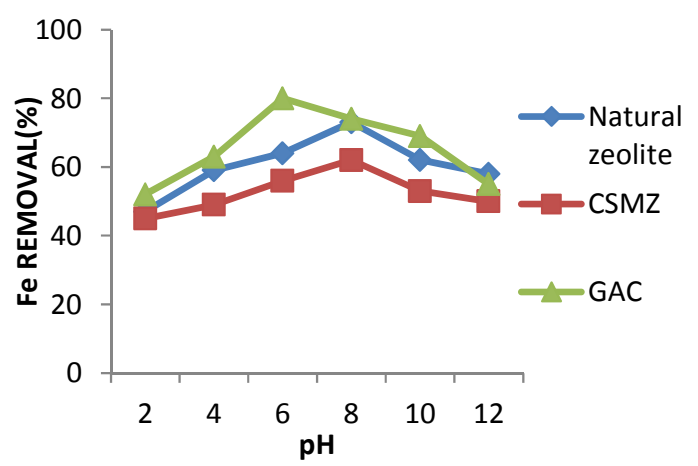

(d)

Figure 2. Percentage of color (a), COD (b), turbidity (c), and Fe (d) removal (\%) against pH for NZ, CSMZ, and GAC

Figure 2(a) shows the maximum removal percentage of colour that was removed by natural zeolite, CSMZ, and granular activated carbon (GAC) which were $79 \%, 90 \%, 82 \%$ respectively. This adsorption is depended on the characteristic of adsorbents itself. For zeolite and CSMZ were related to the amount of cationic ions $\left(\mathrm{Al}^{3+}\right)$ increased, resulting in high reaction activity and GAC was related to the adsorption capacity. It was observed that the adsorption capacity was highly dependent on the $\mathrm{pH}$ of the solution, and indicated that the colour removal efficiencies decreased with the increase of solution $\mathrm{pH}$. 
The $\mathrm{pH}$ of the system exerts profound influence on the adsorptive uptake of adsorbate molecules presumably due to its influence on the surface properties of the adsorbent and ionization or dissociation of the adsorbate molecule. Figure 2(b) represents the percentage removal of natural zeolite and CSMZ where they reach optimum efficiency in removing organic compound (COD) at $\mathrm{pH} 2$ with efficiency of $53 \%$ and $60 \%$ respectively. Meanwhile, the highest percentage removal of COD for GAC was achieved at $\mathrm{pH} 4$ with efficiency obtained about $61 \%$. Identical trends in colour removal were exhibited in percentage removal of COD for natural zeolite, CSMZ and GAC. In fact, this result also reveals that GAC has the highest percentage removal among natural zeolite and CSMZ yet optimum in difference $\mathrm{pH}$ solution. Neutralization mechanism occurs in low $\mathrm{pH}$ makes color removal, COD removal and Turbidity removals at $\mathrm{pH} 2$ are higher for most of absorbents in this process.

In Figure 2(c), percentage turbidity removal against $\mathrm{pH}$ for each adsorbent revealed that optimal reduction of turbidity was obtained in an acidic environment with efficiency removal of $96 \%, 98 \%, 95 \%$ for natural zeolite, CSMZ, and GAC respectively. When the $\mathrm{pH}$ of the solution was adjusted above $\mathrm{pH} 6$ to $\mathrm{pH} 12$, the tendencies of all adsorption performances were gradually decreased. Moreover, it also showed that the lowest efficiency for the three adsorbents were identified at $\mathrm{pH} 12$ with percentage values removal $55 \%, 61 \%$, and $59 \%$ for natural zeolite, CSMZ, and GAC respectively.

Figure 2(d) demonstrates the removal efficiencies of iron ion as a function of the influent $\mathrm{pH}$. The maximum removal of iron ion was observed at $\mathrm{pH} 8$ for both natural zeolite and CSMZ whereas GAC had its optimum removal at $\mathrm{pH}$ 6. Natural zeolite and CSMZ only yielded $73 \%$ and $62 \%$ removal efficiency while GAC had more significant removal with removal efficiency of $80 \%$ to the iron ion concentration. Further, it is evident from the graph that gradual increment of removal efficiency for natural zeolite, CSMZ, and GAC occurred when the initial $\mathrm{pH}$ of the solution was increased to higher values. Somehow, at $\mathrm{pH}$ values greater than 6 the removal efficiency of GAC reduced slightly while for natural zeolite and CSMZ the reduction occurred from $\mathrm{pH}$ values above 8 .

\subsection{Effect of Adsorbent Dosage on the Efficiency of Colour, COD, Turbidity, and Iron Ion ( $\mathrm{Fe}$ ) Removal}

The effect of adsorbent dosage was studied for all adsorbents employed on colour, COD, turbidity, and iron ion removal by varying the dosage of adsorbent and keeping all other experimental conditions constant. The $\mathrm{pH}$ was set to acidic conditions which were most favourable in obtaining the highest removal efficiency. In this study, to find optimal adsorbent dosage of natural zeolite and CSMZ, the appropriate experiments were carried out at adsorbent dosages in the range of $0.5 \mathrm{~g}$ to $5.0 \mathrm{~g}$ while for $\mathrm{GAC}$, the adsorbent dosage was varied from $0.01 \mathrm{~g}$ to 4.0 g. The experimental results for all the adsorbents are represented by Figure 3(a) to Figure 4(d).

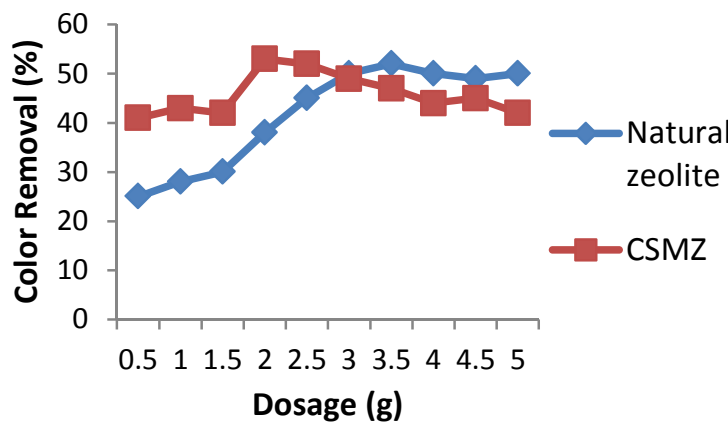

(a)

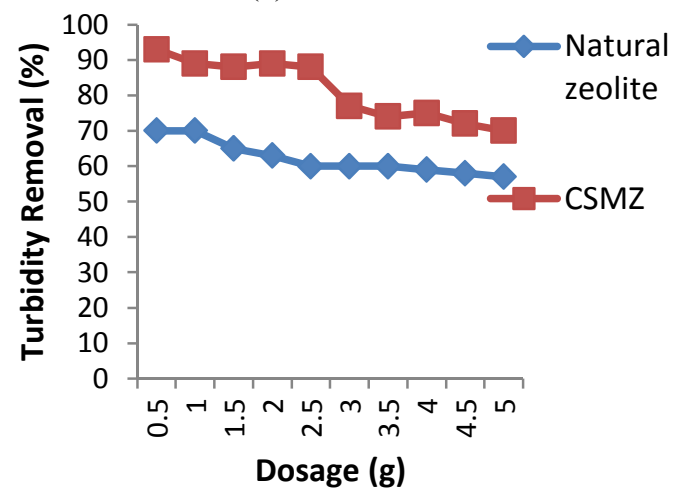

(c)

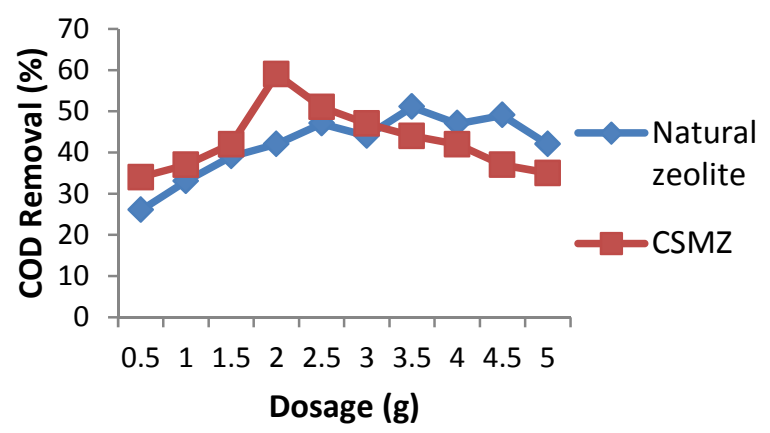

(b)

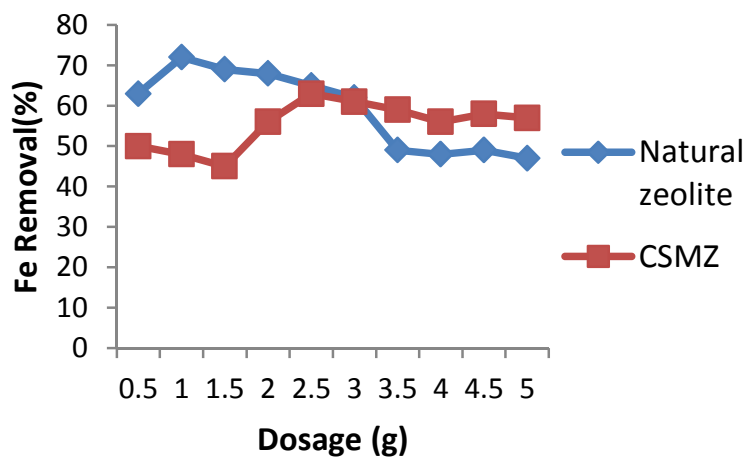

(d)

Figure 3. Percentage of color (a), COD (b), turbidity (c), and Fe (d) removal against $\mathrm{pH}$ for NZ, and CSMZ 
Figure 3(a) displays the relationship between the amount of adsorbent mass (dosage) and adsorption efficiency for natural zeolite and CSMZ in terms of removing colour. The colour removal of peat water increased from about $25 \%$ to $52 \%$ with increasing adsorbent dosage of natural zeolite from $0.5 \mathrm{~g}$ to $3.5 \mathrm{~g}$ whereas for CSMZ, removal percentage increased from $41 \%$ to $53 \%$ with increasing adsorbent dosage from $0.5 \mathrm{~g}$ to $2.0 \mathrm{~g}$. However, further increase in adsorbent dosage to $5.0 \mathrm{~g}$ only led to slight degradation of removal efficiency to $50 \%$ and $41 \%$ for natural zeolite and CSMZ respectively. This degradation with further increases in adsorbent dosage was due to the unsaturated adsorption active sites during the adsorption process since the adsorbates in the vessel were only shaken for 20 minutes (insufficient time). Besides, modification of zeolite by cationic surfactant had proven to have better colour removal as presented in the graph.

Percentage removal of COD against the adsorbent dosage is shown in Figure 3(b). It was observed that the highest percentage removal for both natural zeolite and CSMZ to remove COD were $51 \%$ and $59 \%$, achieved at adsorbent dosage $3.5 \mathrm{~g}$ and $2.0 \mathrm{~g}$ respectively.

The variations in removal of turbidity of peat water at various system $\mathrm{pH}$ are shown in Figure 3(c). The removal rate of turbidity was highest at the adsorbent dosage of $0.5 \mathrm{~g}$ with $70 \%$ and $93 \%$ removal efficiency for respective natural zeolite and CSMZ. The removal rate showed a smooth downward trend with the increase in adsorbent dosage. Concurrently, the adsorption capacity gradually decreased with the increasing adsorbent dosage. The least efficient removal of turbidity was noted at dosage $5.0 \mathrm{~g}$ with percentage removal recorded for natural zeolite and CSMZ only $57 \%$ and $70 \%$ respectively.

Figure 3(d) demonstrates the percentage iron ion removal of natural zeolite and CSMZ with respect to their dosage. The result shows that there was a significant difference trend in iron ion adsorption efficiencies between natural zeolite and CSMZ. For natural zeolite, it was shown that the removal percentage of iron ion had increased until it reached $1.0 \mathrm{~g}$ of dosage with $72 \%$ of removal efficiency. On the other hands, CSMZ was only able to remove about $63 \%$ of iron ion when its dosage was increased to $2.5 \mathrm{~g}$. The lowest percentage removals were $47 \%$ and $57 \%$ recognized at the adsorbent dosage $5.0 \mathrm{~g}$ for respective natural zeolite and CSMZ.

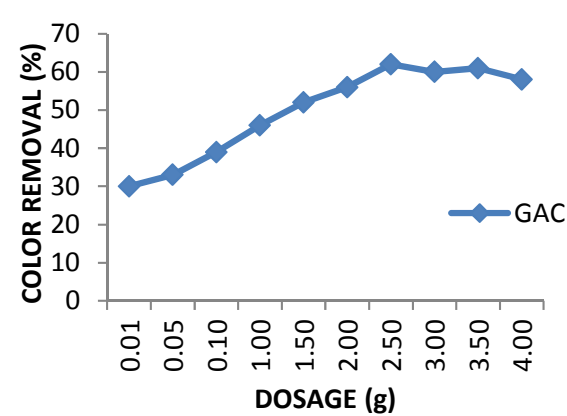

(a)

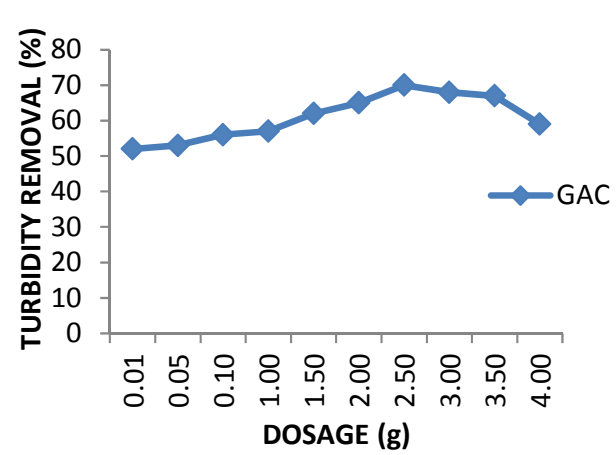

(c)

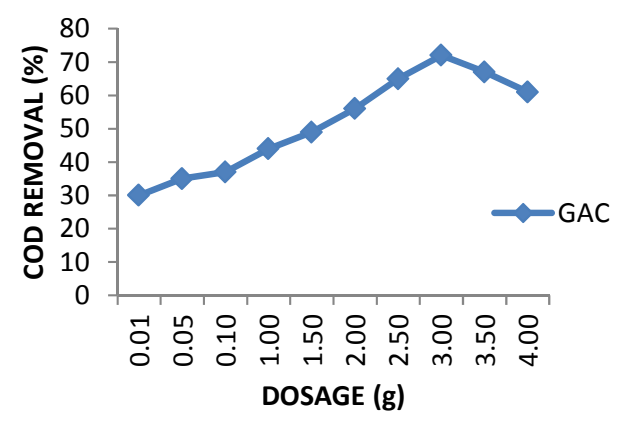

(b)

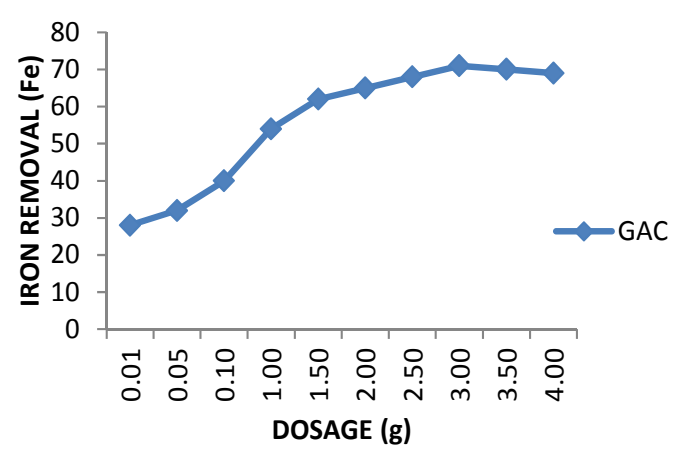

(d)

Figure 4. Percentage of color (a), COD (b), turbidity (c), and Fe (d) removal against dosage for GAC

The result illustrated in Figure 4(a) shows the maximum removal percentage of colour for GAC at $2.5 \mathrm{~g}$ dosage was $62 \%$. Moderate increment in colour removal was identified along with the addition dosage of $2.5 \mathrm{~g}$ whilst abatement of removal efficiency began subsequently at adsorbent dosage of $3.0 \mathrm{~g}$ to $4.0 \mathrm{~g}$. 
The results from Figure 4(b) indicated that increasing the GAC dosage would increase the efficiency in removing COD respectively. The optimum dosage was recorded at $3.0 \mathrm{~g}$ with $72 \%$ of removal efficiency. Meanwhile, increasing the dosage above $3.0 \mathrm{~g}$ exhibited a slight decrease in removal efficiency with $67 \%$ to $61 \%$ for COD removal. A better result in removing COD was also shown by GAC compared to the natural zeolite and CSMZ.

The percentage of turbidity removed by GAC in different dosages is described in Figure 4(c). The highest removal was indicated at adsorbent dosage $2.5 \mathrm{~g}$ with removal efficiency of $70 \%$ while the minimum removal was $52 \%$ recorded at the adsorbent dosage $0.01 \mathrm{~g}$. However, starting from adsorbent dosage of 3.0 to $4.0 \mathrm{~g}$, removal efficiency began to decrease to $68 \%, 67 \%$, and $69 \%$ respectively.

The result of percentage removal of iron ion by GAC in peat water is presented in Figure 4(d). It was found that the rate of removal was rapid in the initial dosage between $0.01 \mathrm{~g}$ to $3.0 \mathrm{~g}$ at which the removal efficiency increased from $28 \%$ to $71 \%$ accordingly. Subsequently, a few significant changes in the rate of removal were observed. Possibly, at the beginning, the solute molecules were absorbed by the exterior surface of adsorbent particles, so the adsorption rate was rapid. However, after the optimum dose was reached, the adsorption of the exterior surface becomes saturated and thereby the molecules will need to diffuse through the pores of the adsorbent into the interior surface of the particle (Ahmad \& Hameed, 2009).

\subsection{Batch Column Experiment}

On the first running, the column was packed with natural zeolite $\left(1^{\text {st }}\right.$ layer $)$, limestone $\left(2^{\text {nd }}\right.$ layer $)$, and GAC $\left(3^{\text {rd }}\right.$ layer) as shown in Figure 5(a). Removal efficiency for colour, COD, turbidity, and iron ion was recognized to be increased when the contact time was increased. At the time interval 1 hour to 6 hours, however, the increment was not so significant. The removal efficiency at 1 hour treatment was $39 \%, 21 \%, 54 \%, 36 \%$ while at 6 hours treatment was $77 \%, 65 \%, 73 \%, 60 \%$ recorded for respective colour, COD, turbidity, and iron ion. Poor removal efficiency at 1 hour treatment indicated that the required time to remove all parameters were insufficient. It is evident that if the adsorption process is allowed to run for 24 hours on the column, the removal efficiency shows notable removal. Percentage removals of colour, COD, turbidity, and iron ion at 24 hours were $83 \%, 72 \%, 76 \%, 65 \%$ respectively. Furthermore, the highest removal for respective colour, COD, turbidity, and iron ion were obtained at 48 hours treatment with $87 \%, 81 \%, 86 \%$, and $79 \%$ of removal efficiency.

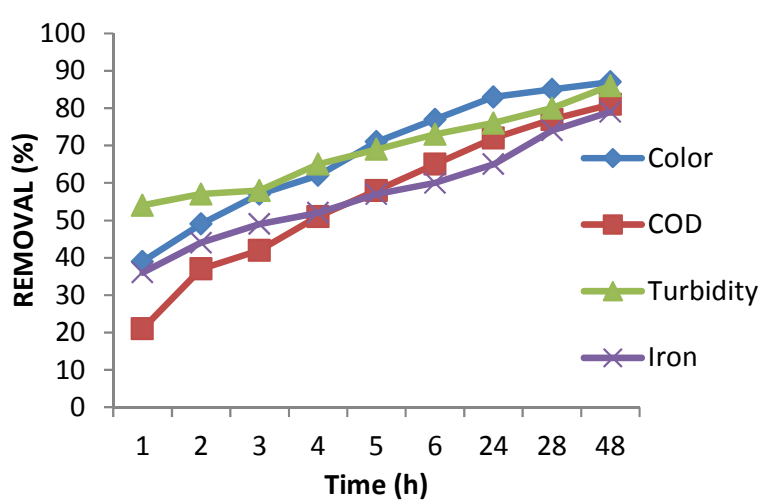

(a)

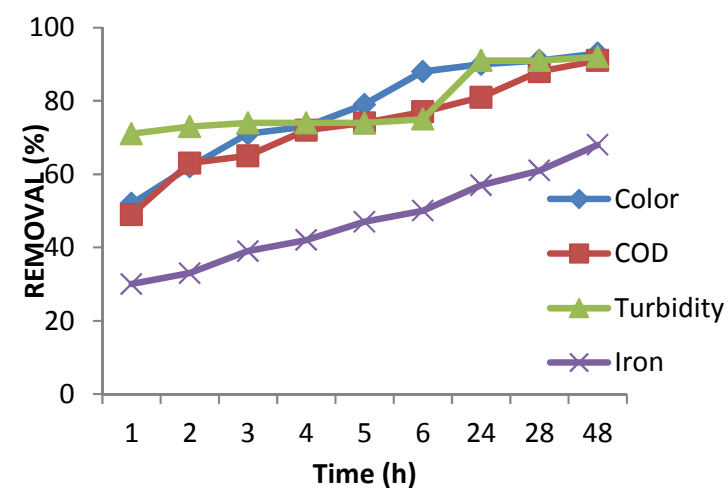

(b)

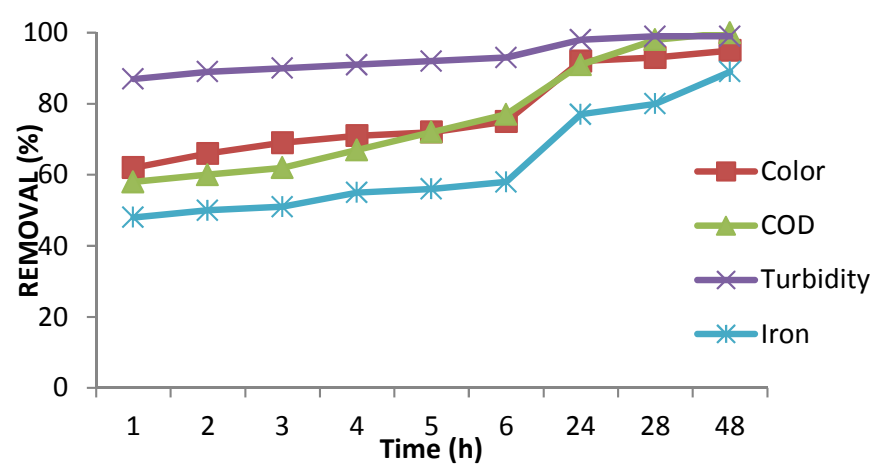

(c)

Figure 5. Percentage removal of color, COD, turbidity, and Fe for 1st run(a), 2nd run(b), and 3rd run (c) at flowrate $30 \mathrm{ml} / \mathrm{min}$ 
On the second running, the column was packed with $\operatorname{CSMZ}\left(1^{\text {st }}\right.$ layer $)$, limestone ( $2^{\text {nd }}$ layer $)$, and GAC ( $3^{\text {rd }}$ layer $)$ as presented in Figure 5(b). The removal percentages of colour, COD, turbidity, and iron ion were noticed after 1 hour to be $52 \%, 49 \%, 71 \%$, and $30 \%$ respectively. The time of contact between adsorbate and adsorbent is proven to play an important role during the uptake of pollutants from peat water samples by adsorption process. In addition, the development of charge on the adsorbent surface was governed by contact time and hence the efficiency and feasibility of an adsorbent for its use in water pollution control can also be predicted by the time taken to attain its equilibrium (Sharma, 2003). Removal efficiency of $90 \%$ for colour, $81 \%$ for COD, $91 \%$ for turbidity, and $57 \%$ for iron ion were obtained at 24 hours of contact time.

On the third running, the column was packed with a difference sequence of CSMZ ( $1{ }^{\text {st }}$ layer $), \operatorname{GAC}\left(2^{\text {nd }}\right.$ layer $)$, and limestone ( $3^{\text {rd }}$ layer) demonstrated in Figure 5(c). It can be seen that the adsorption of these four parameters were slightly rapid at time interval 1 hour to 6 hours treatment. Further gradual increment with the prolongation of contact time form 24 hours to 48 hours has also occurred. Observation at 1 hour treatment recorded the removal efficiency of $62 \%, 58 \%, 87 \%$, and $48 \%$ for respective colour, COD, turbidity, and iron ion. Whereby, 6 hours treatment had yielded higher removal percentage removal of $75 \%, 77 \%, 93 \%$, and $58 \%$ respectively for colour, COD, turbidity, and iron ion. Further removal of colour, COD, turbidity, and iron ion was recorded when the treatment was run for 24 hours which exhibited 92\%, 91\%, 98\%, 77\% of removal efficiency respectively. Prolonged time to 48 hours indeed showed better removal of colour, COD, turbidity, iron ion with percentage removal of $95 \%, 100 \%, 99 \%$, and $89 \%$ respectively. It can be seen that the arrangement of CSMZ, GAC, and limestone has the highest removal efficiency for all parameters at the flow rate influent of $30 \mathrm{ml} / \mathrm{min}$.

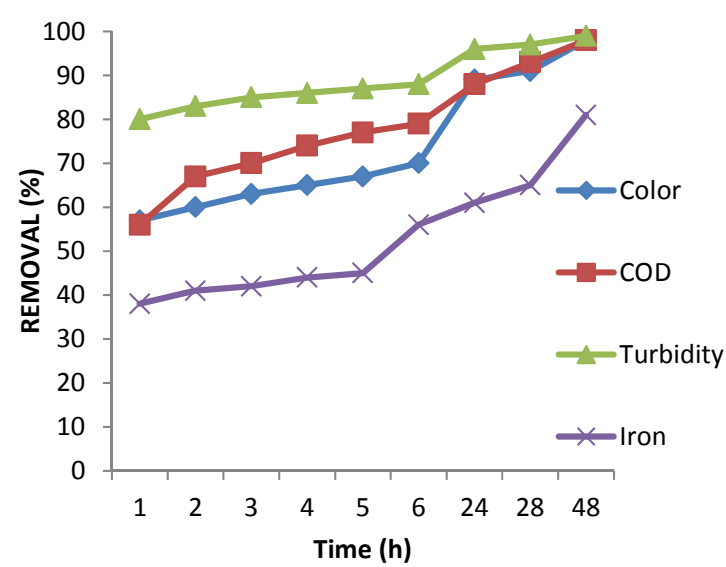

(a)

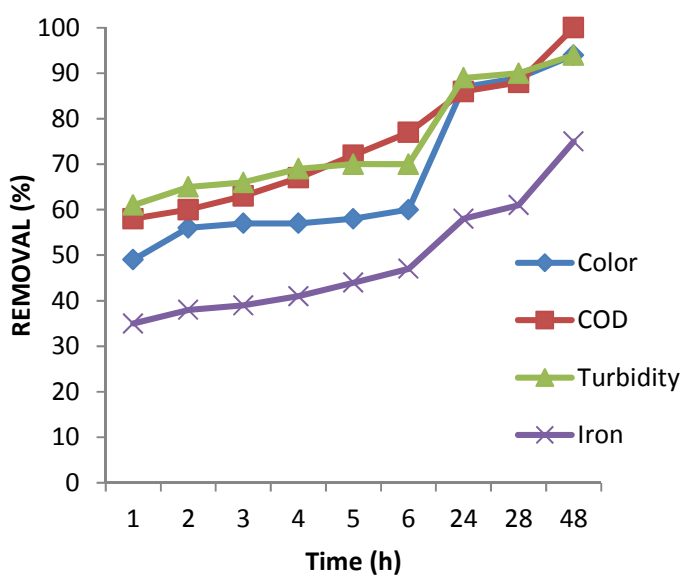

(b)

Figure 6. Percentage removal of color, COD, turbidity, and Fe against contact time for 2 nd run(a) at flow rate 60 $\mathrm{mL} / \mathrm{min}$ and at flowrate $90 \mathrm{~mL} / \mathrm{min}(\mathrm{b})$

The experimental adsorption behaviour was further seen for its adsorption capacity during $60 \mathrm{ml} / \mathrm{min}$ and 90 $\mathrm{ml} / \mathrm{min}$ flow rate. In addition, the flow rate adjustment had also resulted in differences in surface loading rate in which the sample going through the surface area of adsorbent bed (horizontal surface area, $A=22.9 \mathrm{~cm}^{2}$ ) for 30 $\mathrm{ml} / \mathrm{min}$ equals to $1.31 \mathrm{~cm} / \mathrm{min}$ while the flow rate of $60 \mathrm{ml} / \mathrm{min}$ equals to $2.62 \mathrm{~cm} / \mathrm{min}$, and the flow rate of 90 $\mathrm{ml} / \mathrm{min}$ equals to $3.93 \mathrm{~cm} / \mathrm{min}$. The percentage removal for both flow rate adjustments of CSMZ, GAC, and limestone arrangement were exhibited in Figure 6 (a) and Figure 6 (b). Based on these Figures, lower removal efficiencies were indicated at 1 hour time interval of 6 hours of contact time. The percentage removals for both 60 $\mathrm{ml} / \mathrm{min}$ and $90 \mathrm{ml} / \mathrm{min}$ flow rate at 1 hour were $57 \%, 56 \%, 80 \%, 38 \%$ and $49 \%, 58 \%, 61 \%, 35 \%$ for colour, COD, turbidity, and iron ion respectively. Subsequently, when the contact time was at 6 hours, the removal percentage were $70 \%, 79 \%, 88 \%, 56 \%$, and $60 \%, 77 \%, 70 \%, 47 \%$. However, the maximum removal efficiency at 48 hours for both flow rates was not much different from the $30 \mathrm{ml} / \mathrm{min}$ flow rate.

\subsection{Adsorption Isotherm}

In the present investigation, the experimental data were tested with respect to both Freundlich and Langmuir isotherms. Based on the linearized Freundlich isotherm models for natural zeolite, CSMZ, GAC in terms of adsorptive capacity to remove colour, COD, turbidity, and iron ion, the majority of them exhibited fits for all adsorbate with regression value $\left(\mathrm{R}^{2}\right)$ above 0.6 , except for iron ion and turbidity for respective CSMZ, and GAC. On the other hand, the linearized Langmuir isotherm models for natural zeolite, CSMZ, GAC in terms of 
adsorptive capacity to remove colour, COD, turbidity, and iron ion, had exhibited fits for all adsorbate with regression value $\left(\mathrm{R}^{2}\right)$ was at range of 0.242 to 0.912 . The Langmuir isotherm model for all adsorption mechanisms were identified to have smaller $\mathrm{R}^{2}$ values compared to the Freundlich isotherm model. Thereby, it can be concluded that the Freundlich isotherm model was more applicable in determining the adsorption mechanisms for this study.

\subsection{Peat Water Quality Post Column Treatment}

Peat water treatment in column with serial sequence of natural zeolite, CSMZ, and limestone had exhibited the highest removal with percentage removal at 48 hours at $95 \%, 100 \%, 99 \%$, and $89 \%$ for colour, COD, turbidity, and iron ion respectively. Final readings at 48 hours treatment on $\mathrm{pH}$, TDS, DO, conductivity, salinity, colour, turbidity, COD, and iron ion were $7.78,74 \mathrm{mg} / 1,4.03 \mathrm{mg} / 1,137 \mathrm{uS} / \mathrm{cm}, 0.05 \mathrm{ppt}, 12 \mathrm{TCU}, 0.23 \mathrm{NTU}, 0 \mathrm{mg} / 1$, and $0.11 \mathrm{mg} / 1$ respectively (see Table 3). These findings, on the other hand, have indicated that peat water treatment had successfully produced water which satisfied the standard drinking water quality.

Table 3. The characteristics of results of peat water treatment from Beriah Peat Swamp Forest

\begin{tabular}{ccccc}
\hline Parameters & Unit & $\begin{array}{c}\text { Average } \\
\text { Value }\end{array}$ & $\begin{array}{c}\text { Results after 48 } \\
\text { hr }\end{array}$ & $\begin{array}{c}\text { Standard } \\
\text { Limit }^{*}\end{array}$ \\
\hline $\mathrm{pH}$ & - & $4.67-4.98$ & 7.78 & $6.5-9.0$ \\
Temperature & ${ }^{\circ} \mathrm{C}$ & 27.8 & 29 & - \\
$\mathrm{TDS}$ & $\mathrm{mg} / \mathrm{L}$ & 20.6 & 74 & 1000 \\
$\mathrm{DO}$ & $\mathrm{mg} / \mathrm{L}$ & 3.4 & 4.03 & 7 \\
Conductivity & $\mathrm{uS} / \mathrm{cm}$ & 34.5 & 137 & 1000 \\
Salinity & $\mathrm{ppt}$ & 0.02 & 0.05 & 0.5 \\
Color & $\mathrm{TCU}$ & 224.7 & 12 & 15 \\
Turbidity & $\mathrm{NTU}$ & 20.8 & 0.23 & 5 \\
$\mathrm{COD}$ & $\mathrm{mg} / \mathrm{L}$ & 33.3 & 0 & 10 \\
Iron, $(\mathrm{Fe})$ & $\mathrm{mg} / \mathrm{L}$ & 1.24 & 0.11 & 0.3 \\
NH ${ }_{3}-\mathrm{N}$ & $\mathrm{mg} / \mathrm{L}$ & 0.51 & $\mathrm{NA}$ & 1.5 \\
\hline
\end{tabular}

Note: $1 .{ }^{*}$ Malaysian standard for drinking water quality;

2. NA $=$ Not analyzed.

\section{Conclusions}

From the results presented in this paper, the following conclusions can be drawn:

1) The optimum removal of colour, $\mathrm{COD}$, and turbidity for all adsorbents were observed to occur during acidic conditions at $\mathrm{pH}$ range $2-4$ whereas for iron ion, the maximum removal was noted at $\mathrm{pH}$ range $6-8$.

2) At pH 2, CSMZ yielded the highest removal for colour and turbidity with removal efficiency of $90 \%$ and $98 \%$ respectively. Meanwhile, GAC has the highest percentage removal of COD at $\mathrm{pH} 4$ with removal efficiency obtained about $61 \%$ while at $\mathrm{pH} 6$, GAC exhibited the best removal of iron ion with percentage removal around $80 \%$.

3) CSMZ revealed stronger adsorptive capacity for colour, COD, and turbidity compared to natural zeolite.

4) The optimal removal was achieved for the serial sequence of CSMZ ( ${ }^{\text {st }}$ layer), GAC ( $2^{\text {nd }}$ layer), and Limestone ( $3^{\text {rd }}$ layer) with the adsorbent media at $30 \mathrm{ml} / \mathrm{min}$ of flow rate.

5) Freundlich isotherm was more reliable to describe the adsorption mechanisms of colour, COD, turbidity, and iron ion for natural zeolite, CSMZ, and GAC.

\section{Acknowledgement}

The authors wish to acknowledge the financial support from the School of Civil Engineering, Engineering Campus, Universiti Sains Malaysia and Universiti Sains Malaysia (Short Term Grant No. 304/PAWAM/60312015). 


\section{References}

Ahmad, A. A., \& Hameed, B. H. (2009). Reduction of COD and colour of dyeing effluent from a cotton textile mill by adsorption onto bamboo-based activated carbon. Journal of Hazardous Materials, 172, 1538-1543. http://dx.doi.org/10.1016/j.jhazmat.2009.08.025

American Public Health Association (APHA), AWWA, WPCF. (1992). Standard Methods for Examination of Water and Wastewater (16th ed.). Washington.

Bhatmagar, A., \& Minocha, A. K. (2006). Conventional and non-conventional adsorbents for removal of pollutant from water - A review. In Indian Journal of Chemical Technology, 13, 203-217

Botero, W. G., Oliveira, L. C., Rocha, J. C., Rosa, H. R., \& Santos, A. D. (2010). Peat humic substances enriched with nutrients for agricultural applications: competition between nutrients and non-essential meals present in $\begin{array}{llllll}\text { tropical soils. Journal of Hazardous } & \text { Materials, } & \text { 177, } & \text { 307-311. }\end{array}$ http://dx.doi.org/10.1016/j.jhazmat.2009.12.033

Bowman, R. S. (2003). Applications of surfactant-modified zeolites to environmental remediation. Microporous Mesoporous Materials, 61, 43-56. http://dx.doi.org/10.1016/S1387-1811(03)00354-8

Chao, H. P., \& Chen, S. H. (2012). Adsorption characteristics of both cationic and oxyanionic metal ions on hexadecyltrimethylammonium bromide-modified $\mathrm{NaY}$ zeolite. Chemical Engineering Journal, 193-194, 283-289. http://dx.doi.org/10.1016/j.cej.2012.04.059

Ćurković, L., Cerjan-Stefanović, Š., \& Filipan, T. (1997). Metal ion exchange by natural and modified zeolites, Water Research, 31(6), 1379-1382. http://dx.doi.org/10.1016/S0043-1354(96)00411-3

Eltekova, N. A., Berek, D., Novak, I., \& Belliardo, F. (2000). Adsorption of Organic Compounds on Porous Carbon Sorbents. Carbon, 38, 373-377. http://dx.doi.org/10.1016/S0008-6223(99)00113-X

Franceschi, M., Girou, A., Carro-Diaz, A. M., Maurette, M. T., \& Puech-Coste, E. (2002), Optimisation of the coagulation-flocculation process of raw water by optimal design method. Water Research, 36(14), 3561-72.

Fu, F., \& Wang, Q. (2011). Removal of heavy metal ions from wastewaters: A review. Journal of Environmental Management, 92, 407-418. http://dx.doi.org/10.1016/j.jenvman.2010.11.011

Hidaka, T., Hiroshi, T., \& Kishimoto, N. (2003). Advanced treatment of sewage by pre-coagulation and biological filtration process. Water Research, 37(17), 4259-4269. http://dx.doi.org/10.1016/S0043-1354(03)00353-1

Huling, S. G., Robert, G. A., Raymond, A. S., \& Matthew, R. M. (2001). Influence of Peat on Fenton Oxidation. Water Research, 35(7), 1687-1694. http://dx.doi.org/10.1016/S0043-1354(00)00443-7

Jamil, T. S., Ibrahim, H. S., Abd El-Maksoud, I. H., \& El-Wakeel, S. T. (2010). Application of zeolite prepared from Egyptian kaolin for removal of heavy metals: I. Optimum conditions. Desalination, 258, 34-40. http://dx.doi.org/10.1016/j.desal.2010.03.052

Karadag, D., Akgul, E., Tok, S., Erturk, F., Arif Kaya, M., \& Turan, M., (2007). Basic and reactive dye removal using natural and modified zeolite. Journal of Chemical Engineering Data, 52, 2436-2441. http://dx.doi.org/10.1021/je7003726

Liu, T., Chen, Zh. L., Yu, W. Z., Shen, J. M., \& Gregory, J. (2011). Effect of two-stage coagulant addition on coagulation-ultrafiltration process for treatment of humic-rich water. Water Research, 45(14), 4260-4268. http://dx.doi.org/10.1016/j.watres.2011.05.037

Li, Zh. H., \& Bowman, R. S. (2001). Regeneration of surfactant-modified zeolite after saturation with chromate and perchloroethylene. Water Research, 35(1), 322-326. http://dx.doi.org/10.1016/S0043-1354(00)00258-X

Li, Z. H., Jones, H. K., Robert, S., Bowman, \& Helferich, H. (1999). Enhanced Reduction of Chromate and PCE by Pelletized Surfactant Modified Zeolite/Zerovalent Iron. Environmental Science and Technology, 33, 4326-4330. http://dx.doi.org/10.1021/es990334s

Li, Z., Roy, S. J., Zou, Y., \& Bowman, R. S. (1998). Long Term Chemical and Biological Stability of Surfactant Modified Zeolite. Environmental Science Technology, 32, 2628-2632. http://dx.doi.org/10.1021/es970841e

Loo, S. L., Fane, A. G., Krantz, W. B., \& Lim, T. T. (2012). Emergency water supply: A review of potential technologies and selection criteria. Water Research, 46(10), 3125-51. http://dx.doi.org/10.1016/j.watres.2012.03.030 
Paune, F., Caixach, J., Espadaler, I., Om, J., \& Riveraet, J. (1998). Assessment on the removal of organic chemicals from raw and drinking water at a Llobregat river water works plant using GAC. Water Research, 32(11), 3313-3324. http://dx.doi.org/10.1016/S0043-1354(98)00108-0

Rieley, J. O. (1992). The ecology of tropical peatswamp forest \pm a South-east Asian perspective. In Tropical Peat, Proceedings of International Symposium on Tropical Peatland, Kuching, Sarawak, Malaysia, $6 \pm 10$ May 1991 (B.Y. Aminuddin, ed.) pp. 244 \pm 54 . Kuching, Malaysia: Malaysia Agricultural Research Development Institute \& Department of Agriculture, Sarawak, Malaysia

Syafalni, S., Abustan, I., Dahlan, I., \& Wah, C. K. (2012b). Treatment of Dye wastewater Using Granular Activated Carbon and Zeolite Filter. Modern Applied Science, 6(2), 37-51. http://dx.doi.org/10.5539/mas.v6n2p37

Syafalni, S., Abustan, I., Zakaria, S. N. F., \& Zawawi, M. H. (2012a). Raw water treatment using bentonite-chitosan as a coagulant. Water Science \& Technology: Water Supply, 12(4), 480-488. http://dx.doi.org/10.2166/ws.2012.016

Torresdey, J. L., Tang, L., \& Salvador, J. M. (1996). Copper adsorption by esterified and unesterified fractions of sphagnum peat moss and its different humic substances. Journal of Hazardous Materials, 48, 191-206. http://dx.doi.org/10.1016/0304-3894(95)00156-5

World Wildlife Fund (WWF) Malaysia. (2004). The importance of rivers.

Wosten, J. H. M., Clymans, E., Page, S. E., Rieley, J. O., \& Limin, S. H. (2008). Peat- Water interrelationships in a Tropical Peatland Ecosystem in Southeast Asia. Catena, 73, $212-224$. http://dx.doi.org/10.1016/j.catena.2007.07.010

Zhang, P., Tao, X., Li, Z., \& Bowman, R. S. (2002). Enhanced Perchloroethylene Reduction in Column Systems Using Surfactant Modified Zeolite/zero-valent Iron Pellets. Environmental Science and Technology, 36, 3597-3603. http://dx.doi.org/10.1021/es015816u 